\title{
Quantifying the risk mitigation efficiency of changing silvicultural systems under storm risk throughout history
}

\author{
Fabian Müller $^{1}$ (I) $\cdot$ Andrey Lessa Derci Augustynczik ${ }^{1} \cdot$ Marc Hanewinkel $^{1}$
}

Received: 17 April 2019 / Accepted: 1 September 2019 /Published online: 12 December 2019

(C) INRA and Springer-Verlag France SAS, part of Springer Nature 2019

\begin{abstract}
- Key message Silvicultural adaptations throughout history resulted in an increasing mitigation efficiency towards storm risk, quantifiable through an increasing conditional value at risk and decreasing average damage loss. Recently recommended silvicultural systems for spruce stands in Central Europe, like the group selection system, showed the highest mitigation efficiency towards storm, compared to past thinning from below or thinning from above systems.

- Context Storms may affect forests and their productivity. Silvicultural systems adapted throughout history to maintain economic performance of forests under storm risk.

- Aims This paper aims to (i) determine the conditional value at risk (CVaR) as the expected value of the lower 5\% quantile of the simulated economic performance distribution of different silvicultural systems under storm risk, (ii) demonstrate the effect of historical cost and price changes on their performance, and (iii) assess their performance considering revenues from multiple ecosystem services.

- Methods We used an individual-tree growth model to simulate three silvicultural systems, namely thinning from below, thinning from above and group selection. An additive land expectation value is introduced to reflect long-term timber and carbon sequestration revenues. The performance of silvicultural systems under storm risk is assessed, using an empirical storm model combined with Monte Carlo simulations.

- Results The group selection system showed the highest CVaR and therefore highest mitigation efficiency towards storm risk. Moreover, it showed the least sensitivity towards historical cost and price changes. Inclusion of other ecosystem services (carbon sequestration) showed minor sensitivity to storm risk.

- Conclusion Silvicultural adaptations throughout history resulted in increasing mitigation efficiency towards storm risk. Integration of silvicultural adaptation is crucial in the further development of forest management, especially approaching risks from climate change.
\end{abstract}

Keywords Silviculture $\cdot$ Storm risk $\cdot$ Price changes $\cdot$ Carbon sequestration $\cdot$ Risk mitigation

Handling Editor: Celine Meredieu

Contribution of the co-authors Tree growth modelling, economic analyses and elaboration of the article: Fabian Müller

Supervision: Marc Hanewinkel

Storm modelling: Andrey Lessa Derci Augustynczik

This article is part of the topical collection on Risk Analysis

Fabian Müller

fabian.mueller@ife.uni-freiburg.de

1 Faculty of Environment and Natural Resources, University of Freiburg, Tennenbacherstr. 4, 79106 Freiburg, Germany

\section{Introduction}

Between 1950 and 2000, 35 million $\mathrm{m}^{3}$ of wood was damaged in Europe by biotic and abiotic disturbances, with storms being responsible for 53\% of the total damages (Schelhaas et al. 2003). Recent climate change scenarios suggest that extreme events such as storms are expected to become even more detrimental to forest profitability (Lindner et al. 2010). Empirical research shows that one option to mitigate this risk of storm damage is to adapt silvicultural systems, e.g., by changing the tree species composition, thinning intensity, or modifying the structure of the overstorey (Albrecht et al. 2012; Jactel et al. 2009). During the past centuries, silvicultural systems went through major changes, shifting from 
thinning from below, clearcut systems (Hartig 1791) to continuous cover forestry systems (CCF) (ForstBW 2014), substantially modifying stand structure and its sensitivity to storm damage.

Since the 1980s, the Faustmann model is used to determine the effect of natural hazard risks on the economic performance of forest stands (Reed 1984). Haight et al. (1995) discussed the effect of storm risk on the land expectation value (LEV) and showed that the LEV of a young stand is barely affected by storm damages. Loisel (2011) and Loisel (2014) discussed the effect of storm risk on the LEV and showed that storm risk mitigation can be achieved through earlier thinnings and shorter rotation periods. More recently, Rakotoarison and Loisel (2017) challenged the silvicultural management guidelines for beech in Northern France under storm risk, also reflecting price variations throughout the last 30 years.

As indicated by Rakotoarison and Loisel (2017) and shown by Müller and Hanewinkel (2018), besides natural hazards, silvicultural systems have always had to cope with significant cost and price changes. Between 1960 and 2010, the timber price for Norway spruce (Picea abies L.) dropped on average by almost 50\% (Müller and Hanewinkel 2018). This development significantly affected the economic performance of forest enterprises and presumably influences silvicultural decisions as part of the forest management process, since revenues from timber are the major efficiency indicator for forest enterprises (Duncker et al. 2012).

Nevertheless, besides timber production, other ecosystem services from forest management have recently gained importance, from an ecological and societal perspective (Duncker et al. 2012). While for most ecosystem services no market exists, carbon sequestration is traded today on the global financial markets, due to its importance in the context of climate change (Carbon Pulse 2018). Therefore, natural hazards such as storms will not only affect returns from timber sales but also have an impact on carbon sequestration in the future (Lindroth et al. 2009; Thürig et al. 2005).

Although the effects of forest management on stand stability have been investigated, there is still a research gap on the economic performance of forest management, taking into account wood production and ecosystem services under storm risk. Furthermore, existing literature so far has not considered the impact of changing management behavior on risk mitigation efficiency throughout history.

Hence, this paper aims to quantify the risk mitigation efficiency of silvicultural adaptation under storm risk throughout history, reflecting returns from timber production as well as carbon sequestration. This leads to the following research objectives:

(1) Quantify the economic risk mitigation efficiency of different silvicultural systems by determining their conditional value at risk $(\mathrm{CVaR})$ under storm risk.
(2) Analyze the effect of cost and price level changes on the $\mathrm{CVaR}$ as they can be noted throughout history by testing the silvicultural systems in different scenarios against different cost and price levels.

(3) Include additional ecosystem services such as carbon sequestration into the evaluation process to meet current and future development towards revenue diversification in forest management.

To meet these objectives, this article is structured as follows. Firstly, we will define our understanding of risk mitigation efficiency and the CVaR as a quantitative measure. Secondly, we shall introduce the silvicultural systems modelled, based on forest historical knowledge. We then continue by developing an additive LEV, based on the Faustmann theory as economic measure of the evaluation. The storm modeling approach is subsequently introduced as a basis for the determination of the CVaR. Finally, the results of the evaluation process are presented and discussed in a broader context.

\section{Material and methods}

\subsection{Evaluating risk mitigation efficiency}

We understand risk mitigation efficiency as the ability of a silvicultural system to maintain economic performance under given risks. In our case, we aimed to analyze the economic performance of a given silvicultural system under storm risk. Based on the land expectation value (LEV) (Faustmann 1849) that we chose as standard economic measure for a forest stand's economic performance, we introduced the CVaR as a performance indicator which quantifies the mitigation efficiency of the different silvicultural systems under storm risk. We applied the CVaR at a confidence level of $5 \%$. In this case, the $\mathrm{CVaR}$ expresses the mean value of the lower $5 \%$ quantile of the LEV distribution and its maximization implies the maximization of the LEV in worst-case scenarios of storm damage. An additional measure for risk mitigation efficiency is the relative average loss, defined as the average loss which can be expected under storm risk, relative to the economic performance without storm risk.

At this point, we also want to introduce the signal-to-noise ratio as an additional quantitative measure, which enables us to quantify the relative effect that historical cost and price changes have on the LEV of different silvicultural systems. The signal-to-noise ratio is defined by the ratio between mean value and standard deviation yielding an economic performance metric that indicates the average economic performance relative to the risk of cost and price changes observed. The lower the signal-to-noise ratio, the more sensitive the LEV reacts to cost and price changes. 


\subsection{Silvicultural systems defined}

The silvicultural systems defined for this paper represent important silvicultural trends in the last 200 years, which changed silvicultural practice on larger forest areas in Central Europe. For an overview of the different systems and assumptions for tree growth modeling, see Table 1. For comparison purposes, all systems were based on pure Norway spruce stands, although we were aware that increasing proportions of deciduous tree species or other conifers (e.g., silver fir) within these stands have made a substantial change to the silvicultural treatments of the last 200 years. The systems described here were simulated using the single-tree growth simulator BWINPro 7 (Nagel et al. 2017) which was already applied in storm risk-associated research (Albrecht et al. 2015). BWinPro is an individual-tree growth simulator which is distance independent, meaning that "competition between the individuals in the stand is modeled through a distanceindependent competition index" (Albrecht et al. 2015). For simulating the silvicultural systems of the different stands, we used the thinning as well as the harvesting module of the program allowing for customized thinning activities as well as different harvesting types and cadence (Albrecht et al. 2015). As BWinPro is adapted to stands with a homogenous evenaged structure (Albrecht et al. 2015), we could not entirely base our analysis on BWinPro. To simulate an uneven-aged forest stand representing the group selection system, we used BWinPro to simulate the tree growth on group level and afterwards extended to stand level. Therefore, we combined the growth data as well as harvesting related data of groups of different ages so that they represent the age distribution of an uneven-aged stand treated according to the management principles of a group selection system (for a detailed description of all analysis steps of this paper and the simulation data behind, please refer to the public repository by Müller et al. (2019)). To calculate the return from timber sales in different time periods, the respective grading rules were applied to the raw data from BWinPro 7, using the grading algorithms of the software BDAT (Kublin and Bösch 2007). As shown in the following figures, the amount of standing stock as well as the timber volumes harvested significantly differ between the three systems (cf. Figs. 1, 2, and 3). This also results in different height developments with significant differences between the thinning from below and the group selection system respectively the thinning from above and the group selection system due to the uneven-aged structure described with the group selection system (cf. Fig. 4). The figure clearly shows that for this system, the height of the tree with average basal area in the stand $h_{\mathrm{g}}$ is higher at the beginning of the cutting cycle due to the age structure of the whole stand displaying larger groups of old trees.

Table 1 Overview of silvicultural systems selected. Following Hartig (1791), Endres (1895), Abetz (1975), and ForstBW (2014)

\begin{tabular}{|c|c|c|c|}
\hline & 1 Thinning from below & 2 Thinning from above & 3 Group selection \\
\hline Description & $\begin{array}{l}\text { - Thinning from below/clearcut stand } \\
\text { - Even-aged } \\
\text { - Represents time period of } \\
\text { 1850-1910 }\end{array}$ & $\begin{array}{l}\text { - Conservative thinning from } \\
\text { above/stepwise clearcut stand } \\
\text { - Even-aged } \\
\text { - Represents time period of } 1950-1980\end{array}$ & $\begin{array}{l}\text { - Group selection system with the aim of } \\
\text { continuous cover forestry } \\
\text { - Uneven-aged } \\
\text { - Represents time period of } 1980 \text {-today }\end{array}$ \\
\hline $\begin{array}{l}\text { Stand } \\
\text { establishment }\end{array}$ & $\begin{array}{l}\text { - Manual planting with high stem } \\
\text { density resulting in } 3400 \text { trees/ha at } \\
\text { age } 25\end{array}$ & $\begin{array}{l}\text { - Manual planting with reduced stem } \\
\text { density resulting in } 2700 \text { trees/ha at } \\
\text { age } 25\end{array}$ & $\begin{array}{l}\text { - Natural regeneration } \\
\text { - Assumed is a natural regeneration layer under } \\
\text { shelter with tree age of } 5 \text { years at time of group } \\
\text { cutting }\end{array}$ \\
\hline Thinnings & $\begin{array}{l}\text { - Thinning from below with closed } \\
\text { canopy (Hartig 1791) } \\
\text { - Late and conservative thinnings } \\
\text { starting with age 40, next with } 60\end{array}$ & $\begin{array}{l}\text { - Thinnings from above starting at age } \\
30 \text { as described in Abetz (1975) } \\
\text { - Selection of } 350-400 \text { future crop trees } \\
\text { - Every } 5-10 \text { years } \\
\text { - Last thinning at age } 65 \text { as thinning } \\
\text { from below }\end{array}$ & $\begin{array}{l}\text { - Extensive thinnings from above starting at tree } \\
\text { age } 30 \\
\text { - Selection of max. } 200 \text { future crop trees (ForstBW } \\
\text { 2014) } \\
\text { - Every } 5 \text { years (ForstBW 2014) until age } 70 \\
\text { - Care of growing stock at age } 80\end{array}$ \\
\hline Final harvesting & - At age 80 , as clearcut in one step & $\begin{array}{l}\text { - Starting at age } 80 \text { as four step clearcut } \\
\text { every } 5 \text { years }\end{array}$ & $\begin{array}{l}\text { - Group selection system (Femel) as described in } \\
\text { ForstBW (2014) for Norway spruce mixed } \\
\text { stands } \\
\text { - Group age at harvest: } 95 \text { years (crop trees reach } \\
\text { target DBH of } 65 \mathrm{~cm} \text { ) } \\
\text { - Average size of groups cut: } 0.1 \text { ha }\end{array}$ \\
\hline Cutting cycle & - 90 years (Endres 1895) & $\begin{array}{l}100 \text { years (in orientation to Abetz } \\
1975 \text { ) }\end{array}$ & - 90 years \\
\hline Tree species & - Norway spruce & - Norway spruce & - Norway spruce \\
\hline Site index & - Medium $\left(h_{100}=31\right)$ & - Medium $\left(h_{100}=31\right)$ & - Medium $\left(h_{100}=31\right)$ \\
\hline
\end{tabular}


Fig. 1 Timber volume harvested and standing stock per hectare throughout one rotation period for the thinning from below system
Volume havested [cbm/ha] Standing volume $[\mathrm{cbm} / \mathrm{ha}]$

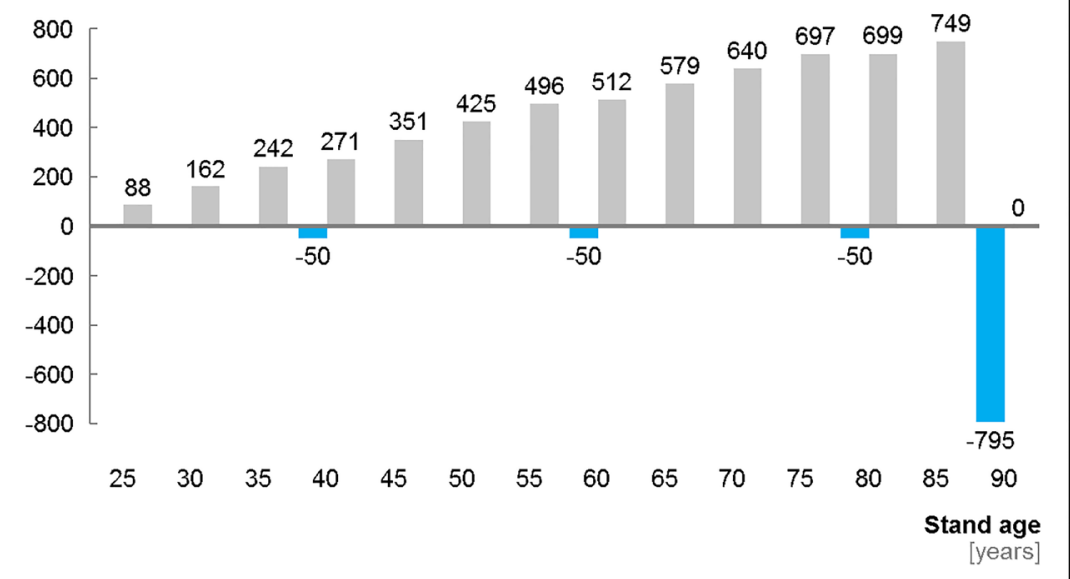

\subsection{Evaluating economic performance}

In this paper, economic performance is not only limited to revenues from timber but also carbon sequestration. Therefore, an additive LEV function ( $\left.L \hat{E} V_{\text {total }}\right)$ simultaneously considering the LEVs of timber production and carbon storage was defined. On a high level of aggregation, the LEV of this paper therefore was defined as:

$\widehat{L E V}_{\text {total }}=\widehat{L E V}_{\text {timber }}+\widehat{L E V}_{\text {carbon }}$

$\widehat{L E V}_{\text {timber }}$ equals the value generated from timber production and sales (cf. Section 2.3.1) and $\widehat{L E V}_{\text {carbon }}$ equals the value generated by carbon sequestration (cf. Section 2.3.2). Furthermore in Section 2.3.3, the impact of storm risk on the additive LEV is included as negative effect on the $\widehat{L E V}_{\text {total }}$.

To determine the economic performance of the silvicultural systems defined in the context of historical price and cost level changes, we adopted the price and cost relations published in Müller and Hanewinkel (2018).
From Müller and Hanewinkel (2018), we derived three different cost and price levels which are used to test the three different silvicultural systems introduced in Section 2.2. To ensure comparability, all nominal price and cost levels identified for the different time periods were adjusted for inflation with the purchasing power equivalents published by German Central Bank (2017). The choice of the discount factor is a determinant of the economic performance of forest management and therefore has to be discussed. In this article, we followed the ideas of Newell and Pizer (2003) and Weitzman (2001), basing our analyses on declining discount rates to reflect the significant uncertainties of environmental economy in general to determine the right discount factor for forest valuation (for further details, see public Müller et al. (2019), file R1). In this context, various authors (Brazee 2018; Davies and Kerr 2015) used the declining discount rates recommended for environmental investments by the British government (Treasury 2003). We are aware that the basis of this rate might be slightly lower for
Fig. 2 Timber volume harvested and standing stock per hectare throughout one rotation period for the thinning from above system

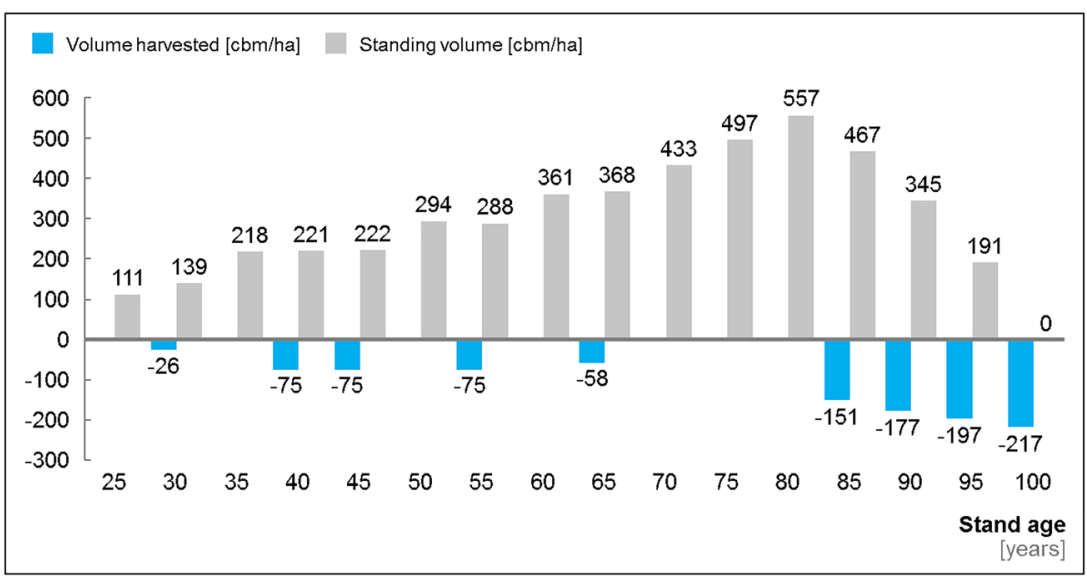




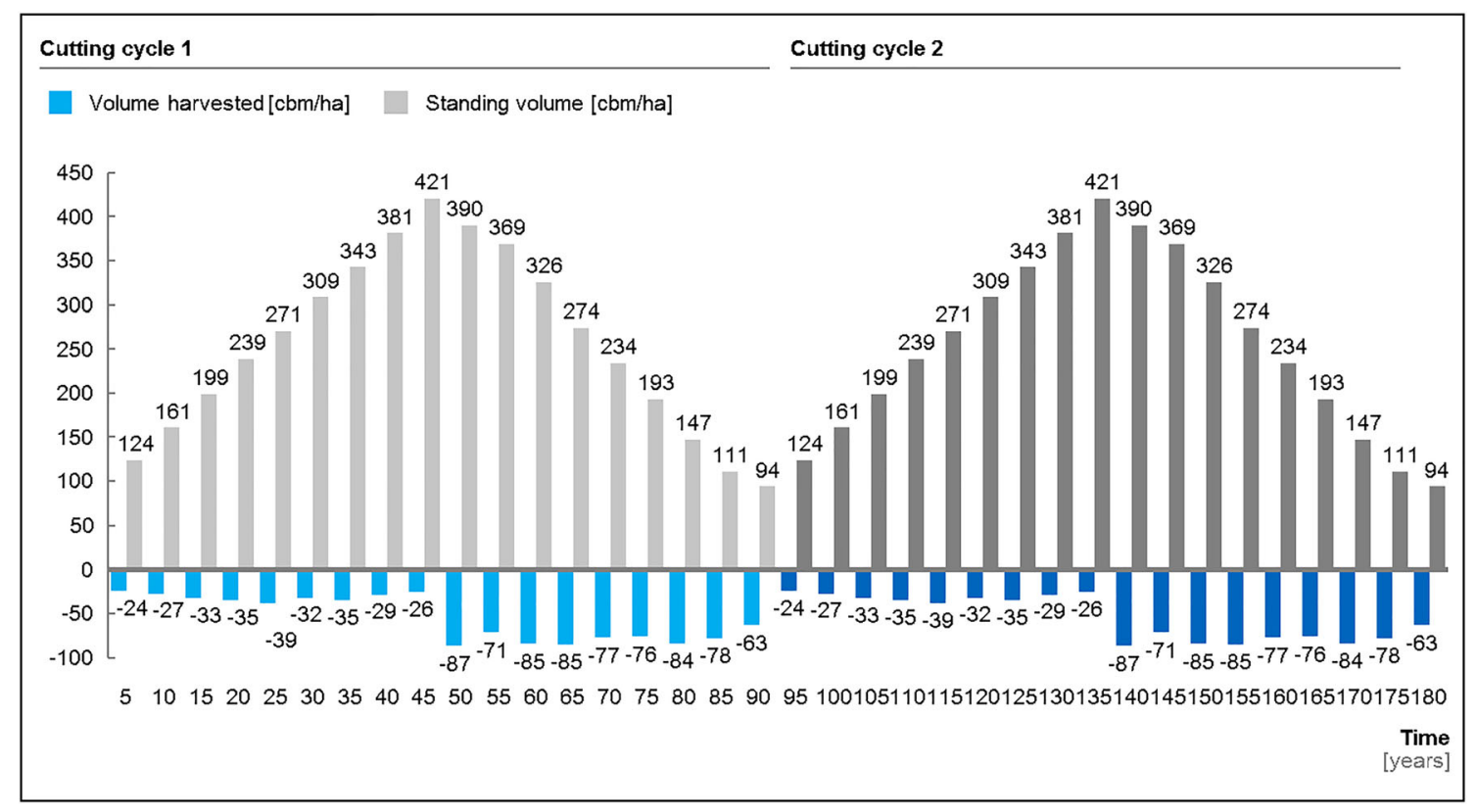

Fig. 3 Timber volume harvested and standing stock per hectare throughout one cutting cycle for the group selection system

Germany than for Great Britain (Oxera Consulting LLP 2002). However, we decided not to adopt the discount rates postulated by Treasury (2003) and refer to the declining discount rates recommended in discrete form (cf. Table 2) as we were also talking about discrete time steps in our silvicultural models.

\subsubsection{Performance of timber production}

The Faustmann model can be seen as the standard approach for evaluating the economic performance of timber production at stand level and is widely used in forest economic research (Newman 2002). The initial idea of Faustmann (1849) was that the value of bare forest land, i.e., the economic performance of growing timber on this land can be determined by reflecting all timber production-induced cash flows starting with stand planting costs $D$ and ending with revenues from the final harvest $E$ after a defined rotation period $T$ :

$L E V=\frac{E_{T}+\sum_{i=1}^{j} R_{i} w^{T-t_{i}}-D w^{T}}{w^{T}-1}-A$

In this formula, revenues from $j$ thinning activities $R_{i}$ at times $t_{i}$ are considered. $T$ denotes the rotation age and $A$ is the capital value of wood production-related annual administration costs. Furthermore, the equation $w=1+v$ holds, where $v$ is the annual discount rate.
Fig. 4 Average height development at stand level for the three different silvicultural systems throughout one cutting cycle. Height describes the height of the tree with mean basal area in the stand $\left(h_{\mathrm{g}}\right)$

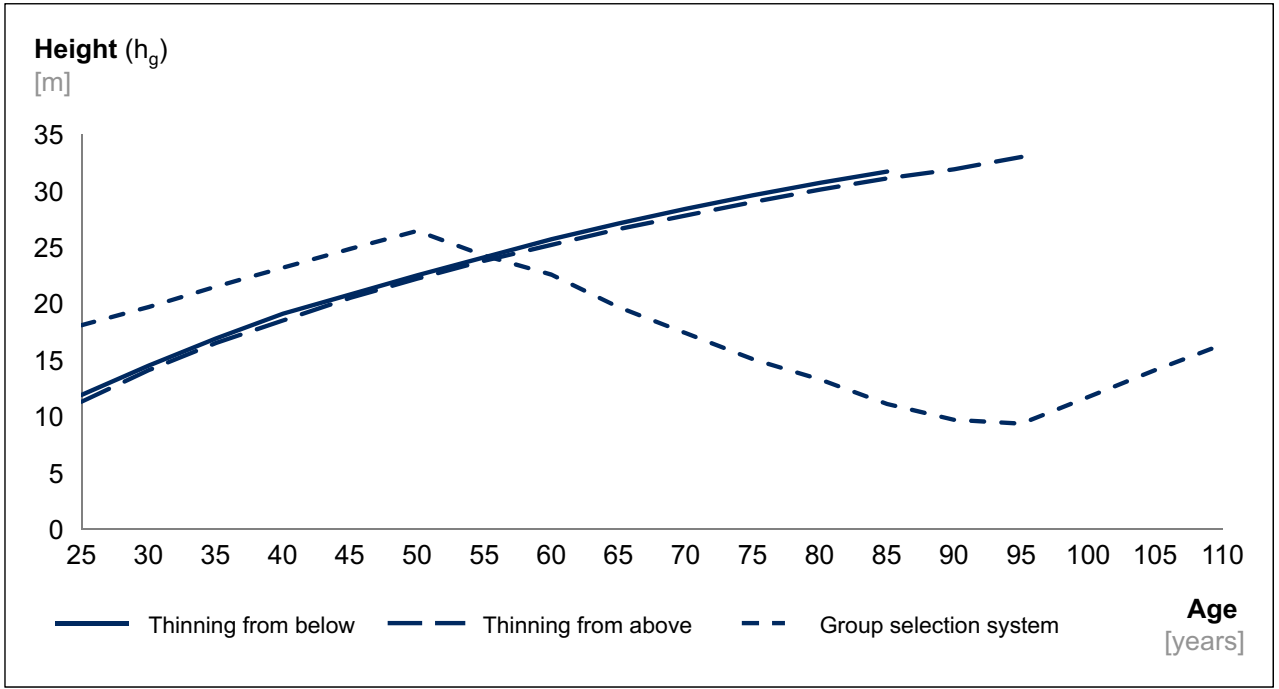


Table 2 Declining discount rates applied in this article (Treasury, 2003). Depending on the period of years simulated, the discount rate is adjusted by $0.5 \%$ until a minimum of $1 \%$ is reached after 300 years

\begin{tabular}{ll}
\hline Period of years & Discount rate $(\%)$ \\
\hline $0-30$ & 3.5 \\
$31-75$ & 3.0 \\
$76-125$ & 2.5 \\
$125-200$ & 2.0 \\
$201-300$ & 1.5 \\
$301+$ & 1.0 \\
\hline
\end{tabular}

Disaggregating Formula (2) into the main timber production-related parameters results in:

$L E V_{\text {timber }}=\frac{-D w^{T}+\sum_{i=1}^{j}\left(\sum_{l=1}^{k}\left(Q_{i, l} P_{i, l}-\frac{Q_{i, l}}{F_{i, l}} L_{i}-\frac{Q_{i, l}}{H_{i, l}} \widehat{\Lambda}_{i}\right)\right) w^{\left(T-t_{i}\right)}}{w^{T}-1}-A$

The formula consists of the following parameters:

- $\quad j$ harvests with harvested volumes $Q_{i, l}$ by timber assortments $l$ at harvest $i$ at harvest age $t_{i}$ where $i=1, \cdots, j, l=$ $1, \cdots, k$ and $t_{i}=t_{1}, \cdots, t_{j-1}, T$ (the final harvesting is defined as the end of the stand rotation period, i.e., at harvest age $T$ )

- timber prices $P_{i, l}$ by timber assortments $l$ at harvest $i$

- technical productivity for felling and processing $F_{i, l}$ as well as haulage $H_{i, l}$ in cbm/h (cubic meters per hour) at harvest $i$ under given technical conditions by timber assortments $l$

- labor and machine costs for felling and processing $L_{i}$ and haulage $\widehat{L}_{i}$ in currency/h at harvest $i$

In our calculations, harvest volumes and times may change significantly depending on the silvicultural system applied. Timber prices as well as labor and machine cost are defined through the three different cost, price, and productivity levels taken into account for the three different epochs analyzed in Müller and Hanewinkel (2018). Moreover, technical productivity is also driven by the silvicultural system, i.e., the natural parameters of the forest stand. In essence, to evaluate the economic performance of the different silvicultural systems regarding different cost and price levels, we calculated nine scenarios building the intersection of the three different silvicultural systems and the three different cost and price levels (cf. Fig. 5). Within each scenario, we assume stable price, wage, and productivity levels for calculating the LEV. This means that price as well as wage levels were assumed as stable per scenario and labor productivity only changed depending on the volumes and dimensions ${ }^{1}$ harvested but not due to technical innovations or process improvements.

\footnotetext{
${ }^{1}$ For simplification reasons, labor productivity is not depending on timber assortments harvested as most of the volumes harvested are long/short timber.
}

Finally, to reflect the concept of declining discount rates, the standard Faustmann formula was adapted using the generalization as formally introduced by Chang (1998), where the LEV can be disaggregated to an infinite number of net present values (NPVs) of infinite rotation periods. Given that the LEV of the simulated stand can be written as the sum of $m$ NPVs and a final LEV for rotation $m T$ being $m$ the number of rotations and $T$ the rotation time. As we assumed declining discount rates $w_{t}$ depending on time $t$ for the first 300 years of the simulation and constant discount rate $w$ of $1 \%$ after 300 years (cf. Table 2), this led to the following equations:

$\widehat{L E V}_{\text {timber }}=\sum_{m \geq 1} N P V_{m}+L E V_{\text {timber }}$

$N P V_{m}$ and $L E V_{\text {timber }}$ are described by the following formulas:

$N P V_{m}= \begin{cases}\frac{-D w_{t}^{T}+\sum_{i=1}^{j}\left(\sum_{l=1}^{k}\left(Q_{i, l} P_{l}-\frac{Q_{i}}{F_{i}} L-\frac{Q_{i}}{H_{i}} \hat{L}\right)\right) w_{t}^{\left(T-t_{i}\right)}}{w_{t}^{T}}-A & \text { form } T \leq 300+T \\ 0 & \text { form } T>300+T\end{cases}$

$L E V_{\text {timber }}=\left\{\begin{array}{lr}\frac{-D w^{T}+\sum_{i=1}^{j}\left(\sum_{l=1}^{k}\left(Q_{i, l} P_{l}-\frac{Q_{i}}{F_{i}} L-\frac{Q_{i}}{H_{i}} \hat{L}\right)\right) w^{\left(T-t_{i}\right)}}{w^{T}-1}-A & \text { form } T>300+T \\ 0 & \text { form } T \leq 300+T\end{array}\right.$

These formulas are applied to the nine different scenarios introduced in this section with changing parameters such as rotation period, harvesting time, volume and assortment mix, as well as harvesting cost and timber price levels.

\subsubsection{Performance of carbon sequestration}

Carbon sequestration within a forest stand throughout a period of time could be calculated as (Yousefpour and Hanewinkel 2009):

$C_{\text {total }}=\sum_{t=1}^{T}\left(C_{t}^{\text {above }}-C_{t-1}^{\text {above }}-C_{t}^{\text {harvest }}-C_{t}^{\text {mortality }}+C_{t}^{\text {below }}-C_{t-1}^{\text {below }}\right)$

Where $C_{t}^{a b o v e}$ and $C_{t-1}^{a b o v e}$ are the carbon stored above at times $t$ and $t-1, C_{t}^{\text {below }}$ and $C_{t-1}^{\text {below }}$ are the carbon stored below ground at times $t$ and $t-1, C_{t}^{\text {harvest }}$ is carbon mobilized by harvesting operations and timber usage, and $C_{t}^{\text {mortality }}$ is carbon released through natural mortality at time $t$. Although a large part of the carbon stock is located below ground (Dieter and Elsasser 2002), we neglected the dynamics of soil organic carbon in managed forests, as their relation to management activities has not yet been analyzed on a level where conclusions about the long-term effects of different harvest regimes can be drawn (Lundmark et al. 2016; Wäldchen et al. 2013).

To conclude, with this approach, we decided to limit our focus on the net carbon uptake and release induced by timber growth, mortality, and harvest assuming that all timber harvested is directly released after the harvest. With this 


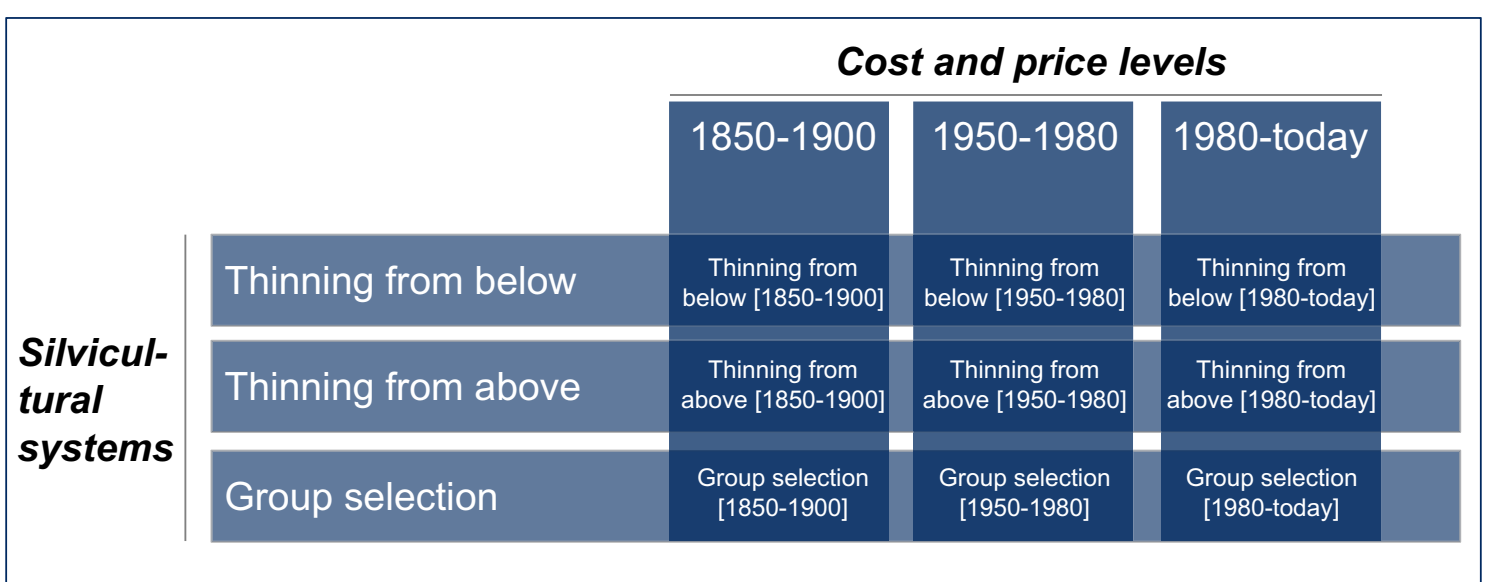

Fig. 5 The figure shows the description of the different scenarios tested in our analysis, as a combination of three silvicultural systems (thinning from below, thinning from above, and group selection) and three cost/price levels, representing different epochs in history

assumption, we followed the concept of the Kyoto protocol where carbon stock changes in harvested wood products are not accounted for (Tonosaki 2009). The reason for that simplification is that carbon sequestration in harvested wood products very much depends on their usage and recycling (Skog 2008). As we were comparing wood utilization over the last 150 years, it was not possible to clearly determine in which time period which amount of wood was used in a form which led to long-term carbon sequestration. In other words, making reasonable assumptions about carbon sequestration of historical wood products was impractical at this point.

The amount of carbon sequestered in the standing stock (excl. roots) was derived directly from the BWINPro simulations, as the rate of carbon uptake is proportional to its volume, i.e., dry biomass growth and related harvesting operations (Creedy and Wurzbacher 2001; Yousefpour and Hanewinkel 2009). The value of sequestering $C_{\text {total }}$ tons of carbon/ha could be finally calculated based on the deflated average $\mathrm{CO}_{2}$ European Emission Allowances Price 2009-2018 $P_{c}$ of 9.27 EUR/t $\mathrm{CO}_{2}$ (Insider Inc. and finanzen.net $\mathrm{GmbH}$ 2018). The LEV for carbon sequestration, $L E V_{\text {carbon }}$, within the simulated stand was finally calculated based on the biomass balance, i.e., the net carbon uptake per period (Gutrich and Howarth 2007) (for further details, see Müller et al. (2019), R1).

\subsubsection{Performance under storm risk}

For modeling the effect of a storm on the net profits from wood harvesting, we assumed that the net profit from harvesting a stand was $50 \%$ below the net profits without storm, due to the effect of quality losses and the oversupply on the timber market (Dieter 2001). Furthermore, it was assumed that if only parts of the stand were damaged, the respective area was then substituted with newly planted trees which restarted like the starting stand at age 0 , growing until the rotation time $T$ of the initial stand.
To model the probability of occurrence and the intensity as well as the impact of a storm, we decided to choose the model "Lothar" of Schmidt et al. (2010), which is fitting the regional setting of southwest Germany and is widely used in science and practice for determining the storm risk of forest stands. Schmidt et al. (2010) applied a statistical modeling approach, based on a large empirical dataset of the damage caused by the storm Lothar. The model developed by the authors computed the damage probability for a tree on a forest stand, based on the tree stability, the stand exposure, and a smoothing function taking the stand location as input. In this model, tree stability was measured through tree height and diameter at breast height (DBH) and is species-specific; the stand exposure being computed based on the Topex-to-distance index and the smoothing function acted as a proxy for the wind speed in this storm event:

$g\left(\pi_{i}\right)=\beta_{1 i}+\beta_{2 i} \log (D B H)+\beta_{3 i} \log (h)+\beta_{4 i}$ Toptodist 1

$+\beta_{5 i}$ Toptodist $2+\beta_{6 i}$ Toptodist $3+\beta_{7 i}$ Toptodist $4+f(N, E)$

Where $g\left(\pi_{i}\right)$ is the logit link function of the damage probability for species $i, \beta_{i j}$ are species-specific model parameters, Top _to _ dist 1 to Top ${ }_{-}$to _ dist4 are the Topex-to-index metric (sum of angles of terrain slopes in four wind directions), and $f(N, E)$ is the smoothing function based on the easting and northing of the stand's coordinates.

We tested here storm recurrence periods of 50 (Albrecht et al. 2019), 100, and 150 years to evaluate the sensitivity of the LEV towards the frequency of damage (implying a yearly occurrence probability of $0.02,0.01$, and 0.0067$)$. To compute the impacts of storm risk on the LEV of forest stands, we performed a Monte Carlo simulation along the rotation age of each silvicultural system, using 1000 repetitions and using the height of the tree with average basal area in the stand $\left(h_{\mathrm{g}}\right)$. In the scenarios where a storm occurred (randomly generated number below the yearly storm probability), we sampled the 
damage probability of the average tree in the stand based on the confidence interval of the storm model's predictions, and assumed that a proportion of the stand compatible with this probability was damaged. The damaged volume was then added to the harvesting pool and the standing stock of subsequent periods was corrected. Moreover, we assumed a new stand was established in the damaged area in the same period of the storm occurrence and we omitted the Topex-to-distance index effect, setting their sum to 0 , in order to disentangle the impacts of the different silvicultural systems on stand structure and stability.

To evaluate the impacts of storm events on the management output, we used the data from the Monte Carlo simulations to compute the conditional value at risk $(\mathrm{CVaR})$ of the LEV distribution generated, at a 5\% confidence level (Eq. 9).

$$
\operatorname{CVaR}_{\alpha}\left(\widehat{L E V}_{\text {total }}\right)=E\left[\widehat{L E V}_{\text {total }} \mid \widehat{L E V}_{\text {total }} \leq \operatorname{VaR}_{\alpha}\right]
$$

Where $\mathrm{CVaR}_{\alpha}$ is the conditional value at risk at the $\alpha$ confidence level, $\widehat{L E V}_{\text {total }}$ is the uncertain additive land expectation value, $E$ is the expected value operator, and $V a R_{\alpha}$ is the value at risk at the $\alpha$-confidence level.

\subsection{Data availability}

The datasets generated and analyzed during the current study are available in the Zenodo repository (Müller et al. 2019) at https://doi.org/10.5281/zenodo.2636500.

\section{Results}

\subsection{The effect of storm risk}

The economic performance of the different silvicultural systems was closely related to the wood utilization rates and timing of harvestings. The total volume harvested amounted to 945,1051 , and $912 \mathrm{~m}^{3} /$ ha for thinning from below, conservative thinning from above, and the group selection system, respectively. The thinning from below and thinning from above systems were characterized by a huge accumulation of cash, which was liquidated only at the end of the rotation periods, whereas the group selection system generated continuous positive cash flows throughout the whole cutting cycle (see Müller et al. (2019), R2, Fig. PR1-PR3). The amount of invested cash varied significantly, with the group selection system standing out due to an initial negative cash flow representing the opportunity costs of the standing stock which were considered for LEV calculations (see Müller et al. (2019), R2, Fig. PR3). The value of the standing stock was evaluated at the beginning of the cutting cycle.
The probability of storm damage differed substantially among the different silvicultural systems (cf. Fig. 6). We perceived that the probability of storm damage was closely associated to the development stage of the stand, i.e., its age and standing stock. Until the age of 50, the group selection system displayed the highest damage probability, since the standing stock in this system remained above $100 \mathrm{~m}^{3} /$ ha throughout the cutting cycle (cf. Fig. 6), thus with higher exposure compared to the other systems. After this point in time (and 60 years for thinning from above), the damage probability of the thinning from below and thinning from above systems rapidly increased, accompanying the standing stock of the stand. Thinning from below showed a peak at the end of the rotation length, since the standing stock was considerably higher for this silvicultural system (cf. Fig. 1). Moreover, the unfavorable $\mathrm{h} / \mathrm{DBH}$ (height/DBH) ratio under this system, ranging from 0.87 to 1.09 , negatively affected tree stability. Considering the full cutting cycle, the group selection system showed the lowest damage probability, followed by conservative thinning from above and thinning from below (area under curve $=11.6,13.3$, and 15.8) (cf. Fig. 6).

The impact of storm risk on the $\widehat{L E V}_{\text {total }}$ of the different silvicultural systems under different cost and price levels is displayed in Fig. 7. The inclusion of storm risk in the LEV calculation led to a skewed LEV distribution, resulting from the losses of storm events (cf. Fig. 7). Focusing our analysis here on the scenarios at cost and price level of 1980-today, we perceived that, as expected, the mean $\widehat{L E V}_{\text {total }}$ under storm risk was lower than the $\widehat{L E V}_{\text {total }}$ without storm risk in all systems (cf. Table 3). Furthermore, similar profitability patterns to the ones obtained without storm damage could be detected, where the group selection system had the highest expected $\widehat{L E V}_{\text {total }}$ (cf. Table 3). The group selection system showed the highest CVaR across all silvicultural systems, whereas the thinning from below system displayed the highest average loss relative to the $\widehat{L E V}_{\text {total }}$ due to storm damage, evidenced by the lowest CVaR (cf. Fig. 8). We highlight here that we observed a larger probability of low impact damage under the group selection system, since it maintained a higher standing stock at initial ages of the stand, compared to other silvicultural systems (cf. Table 3). In our analysis, the storm events did not fully damage the stands, i.e., a proportion of trees remained standing depending on stand structure and management. In this context, due to the large stock accumulation in the thinning from above system, storms occurring later in the rotation period caused a substantial profitability loss. Storm events occurring at early stand ages, however, did not significantly affect forest profitability for thinning from below and thinning from above systems.

The recurrence period of the storm had a decisive impact on both the profitability and risk of different silvicultural systems (cf. Fig. 8). The CVaR was substantially reduced when 
Fig. 6 Storm damage probability along the rotation age for each silvicultural system considered in this study. The shaded area indicates the $95 \%$ confidence interval of damage probabilities

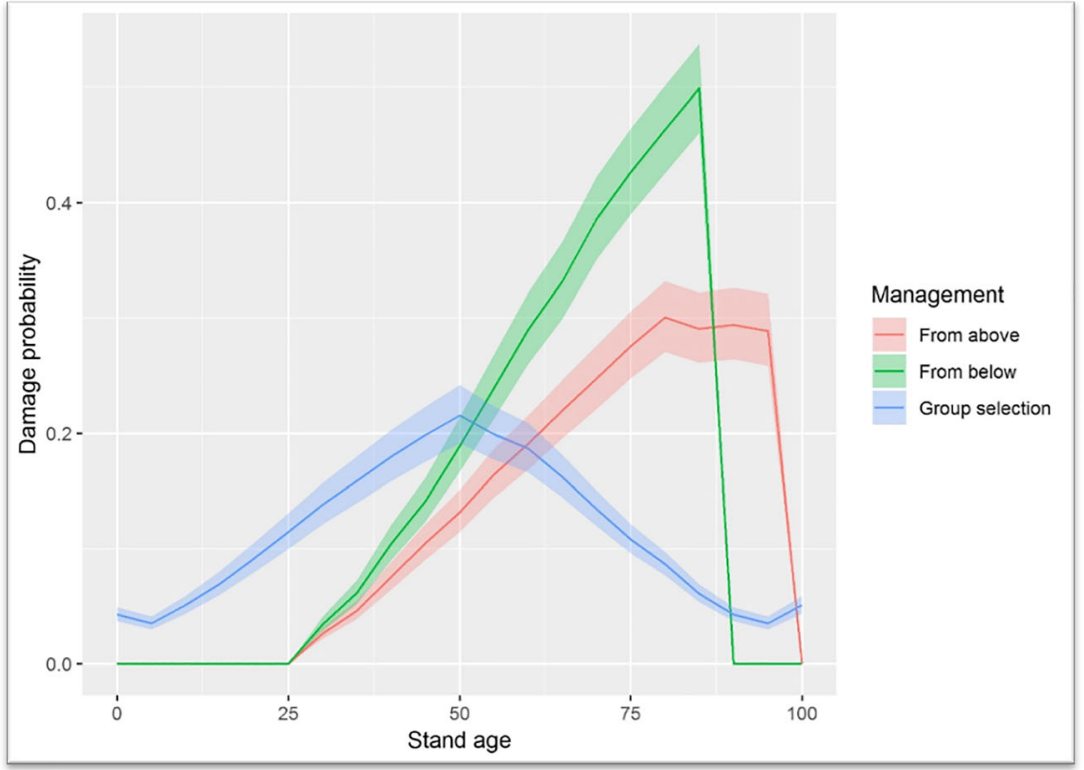

storm recurrence period decreased from 150 to 50 years, especially for the thinning from below silvicultural system. For example, a decrease in recurrence period from 150 to 50 years under cost and price levels of 1850-1900 caused a CVaR loss of $40 \%, 19 \%$, and $14 \%$ for the thinning from below, thinning from above, and group selection systems, respectively. The group selection system also showed the highest robustness towards storm damage for the remaining time periods, followed by the thinning from above system.

The $\widehat{L E V}_{\text {total }}$ computation (including storm damage) in our analysis had the caveat of assuming that in each simulation, the storm would occur at the same age across all rotations for a single Monte Carlo simulation. We highlight, however, that the aggregated effect of storm events across all scenarios applied in our approach includes storm events occurring at different stand ages, thus mimicking a stochastic storm recurrence period. Nevertheless, to demonstrate the implications of storms occurring at different stand ages for a single scenario, we computed the impacts of storm damage on the NPV of the different forest stands (see Müller et al. (2019), R2, Fig. PR4). The NPV of the first rotation had a large contribution (> $80 \%$ ) to the $\widehat{L E V}_{\text {total }}$ and the same patterns obtained in the $\widehat{L E V}_{\text {total }}$ computations were maintained in the NPV analysis.

\subsection{The effect of cost and price changes}

The absolute level of the LEV without storm risk was driving the LEV under storm risk as shown in Table 3. Therefore, it is necessary to reflect the effect of cost and price changes as an influencing factor of the LEV. Table 4 shows the $\widehat{L E V}_{\text {timber }}$ which was calculated under different cost and price levels as they could be identified throughout history. We neglected the $\widehat{L E V}_{\text {carbon }}$ in this section because cost and price changes for carbon sequestration could not be recorded, as we assumed a stable price for carbon sequestration throughout history in this article (cf. Section 2.3.2). It is shown in Table 4 that the $\widehat{L E V}_{\text {timber }}$ of the silvicultural systems significantly changed under different cost and price levels applied. From this observation, two conclusions could be drawn.

Firstly, the analysis gave an idea of the sensitivity of the different silvicultural systems towards the risk of harvesting cost and timber price changes. The signal-to-noise ratio of the different systems indicated that the thinning from below system reacted most sensitively to changes in costs and prices as they occurred throughout the last two centuries. One reason therefore was the high stand establishment costs mentioned. Moreover, the harvesting efficiency to harvest small diameter timber was comparably low (cf. Müller et al. (2019), R2, Fig. PR5). The highest signal-to-noise ratio could be achieved with the group selection system. The signal-to-noise ratio of the thinning from above system lay between those of the other systems, although this system significantly suffered from labor cost increases between the time period of 1950-1980 and 1980-today.

Secondly, Table 4 highlights that the silvicultural innovations as described in this paper significantly increased the profitability of wood utilization throughout history under storm risk. The $\widehat{L E V}_{\text {timber }}$ was negative under the cost and price level of 1980-today for the thinning from above system and even more for the thinning from below system. The reasons therefore were high labor costs for planting and harvesting as well as lower timber prices compared to the other time periods (Müller and Hanewinkel 2018). As the interest effects 
From Below

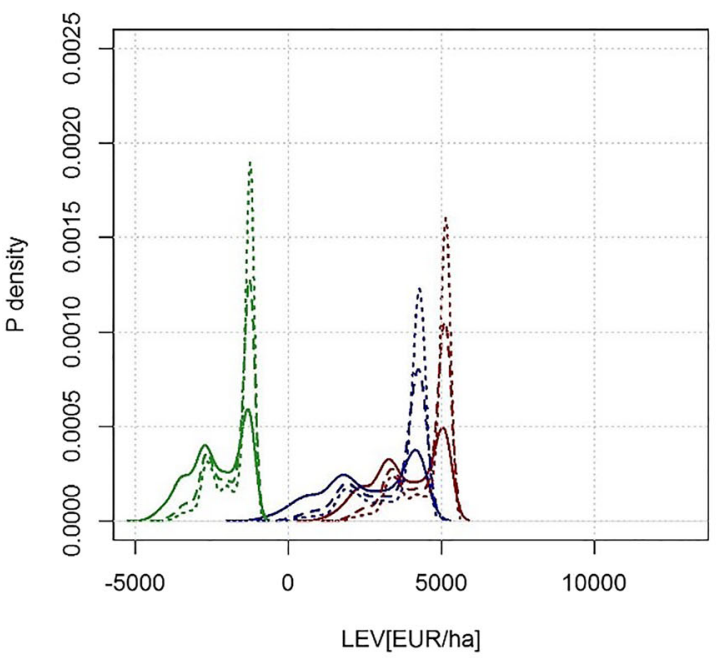

Group selection

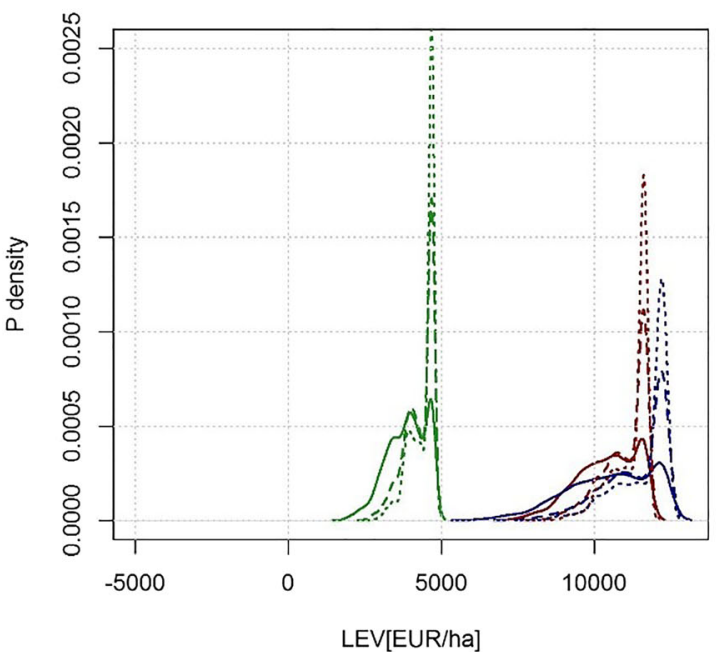

From above

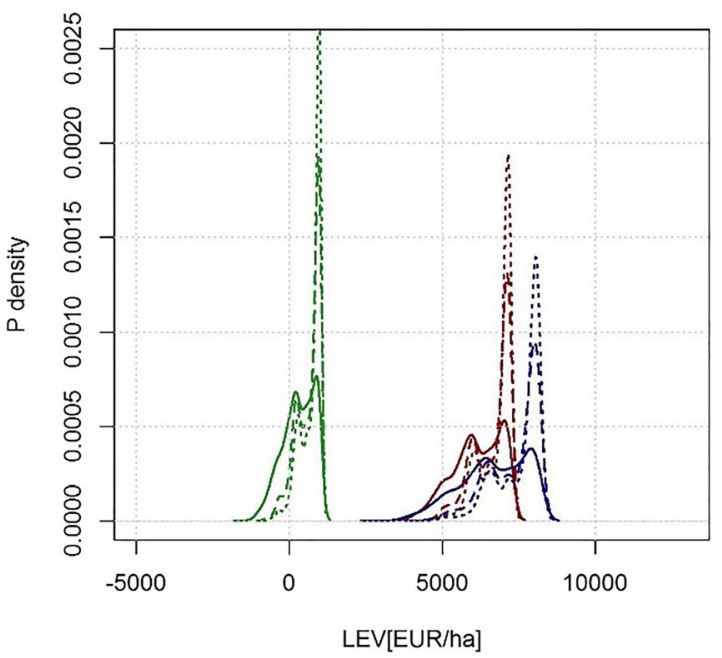

Time period

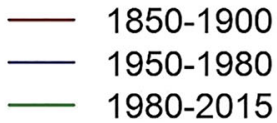

Recurrence period

- 50 years

- - 100 years

..... 150 years

Fig. 7 Land expectation value $\left(\widehat{L E V}_{\text {total }}\right)$ under storm risk for each silvicultural system, recurrence period, and cost and price level tested in this study

on the planting costs in the first rotation neutralized each other, the $\widehat{L E V}_{\text {timber }}$ was reduced by the planting cost factor. If planting costs were neglected, the $\widehat{L E V}_{\text {timber }}$ for the conservative thinning from above system would significantly improve (see Müller et al. (2019), R3-8). Finally, it could be observed that thinning from below showed the best outcomes under the price level of 1850-1910, being subsequently outperformed by conservative thinning from above in the remaining time periods. This was mainly driven by the fact that harvesting costs for small tree dimensions increased disproportionately between the late nineteenth century and the time period of 1950-1980.
Table $3 \widehat{L E V}_{\text {total }}$ under storm risk for each silvicultural system at comparable cost and price level of 1980-today and a 50-year recurrence period

\begin{tabular}{lclll}
\hline & No risk & Under storm risk & \\
\cline { 3 - 5 } & $L E V_{\text {total }}$ [EUR 2016] & Mean [EUR 2016] & $\begin{array}{l}\text { Relative average } \\
\text { loss (\%) }\end{array}$ & CVaR [EUR 2016] \\
\hline Thinning from below & -1239 & & 87 & -4105 \\
Thinning from above & 969 & -2312 & 69 & -836 \\
Group selection & 4678 & 3867 & 17 & 2420 \\
\hline
\end{tabular}


Fig. 8 Conditional value at risk for each silvicultural system, time period, and recurrence period tested in this study

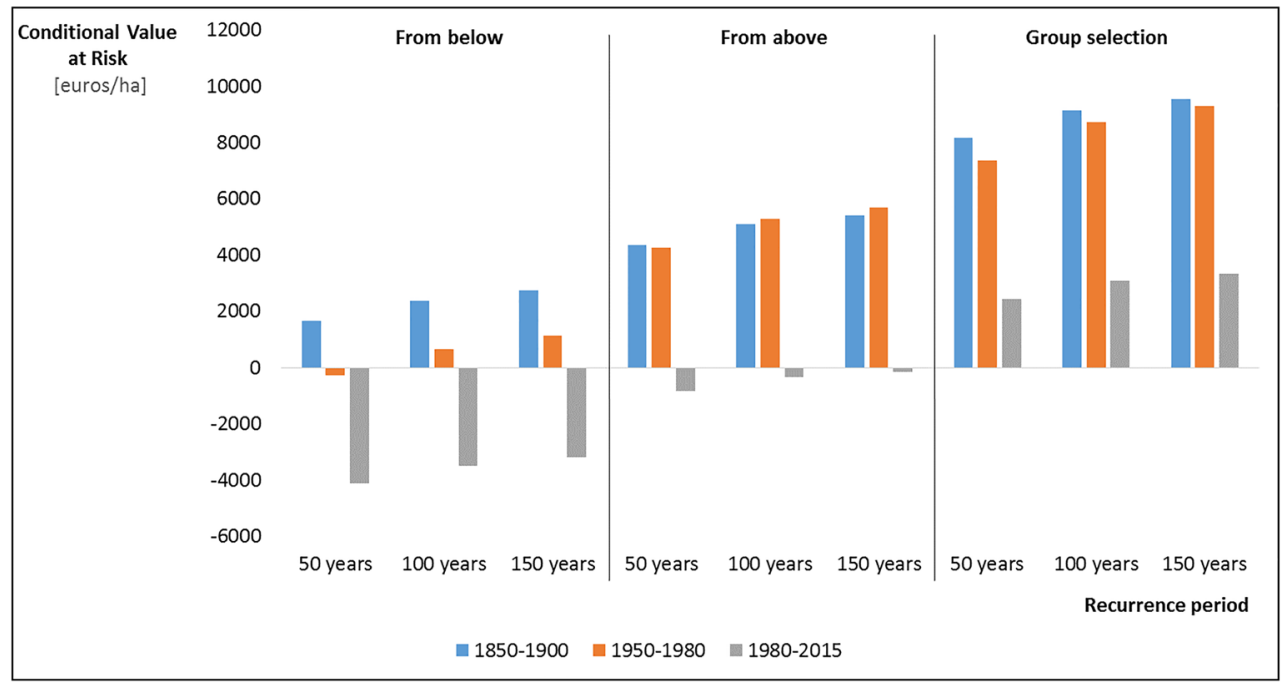

silvicultural systems, as we assumed the same price per ton of carbon for every time period (cf. Section 2.3.2).

The revenues generated by carbon sequestration were barely affected by storm damage and therefore had a small effect on the total profitability of a forest stand under storm risk. The analysis showed that only minor losses in the carbon revenues of around $1 \%$ could be recorded. We will discuss this phenomenon in Section 4.3.

\section{Discussion}

\subsection{Risk mitigation efficiency}

As shown in Section 3, the choice of the silvicultural system significantly affects the CVaR and damage probability, as well as relative average loss of a forest stand under storm risk. Stand and single-tree stability can be seen as major influencing factors for the economic performance of a forest stand under storm risk. Especially the choice of the thinning strategy and the resulting competition between the trees influence the single-tree stability directly (Albrecht et al. 2012). Besides tree height (cf. Fig. 4), the h/DBH ratio particularly drives the storm damage probability in spruce stands, although it is critically discussed as general tree stability measure (Albrecht 2009). Hein et al. (2007) show that the h/DBH ratio can be

Table $4 \widehat{L E V}_{\text {timber }}$ of the nine different scenarios defined by the different silvicultural systems at different price and cost levels

Cost and price level

\begin{tabular}{llccc}
\cline { 2 - 4 }$\widehat{L E V}_{\text {timber }}[\mathrm{EUR}$ 2016] & $1850-1900$ & $1950-1980$ & 1980 -today & Signal-to-noise ratio \\
\hline Thinning from below & 3797 & 2941 & -2595 & 0.4 \\
Thinning from above & 6038 & 6954 & -143 & 1.1 \\
Group selection & 9996 & 10,584 & 3057 & 1.9 \\
\hline
\end{tabular}


Fig. 9 Net carbon balance of the thinning from below system throughout one rotation period in tons of carbon per hectare. Negative values show carbon release through timber harvesting

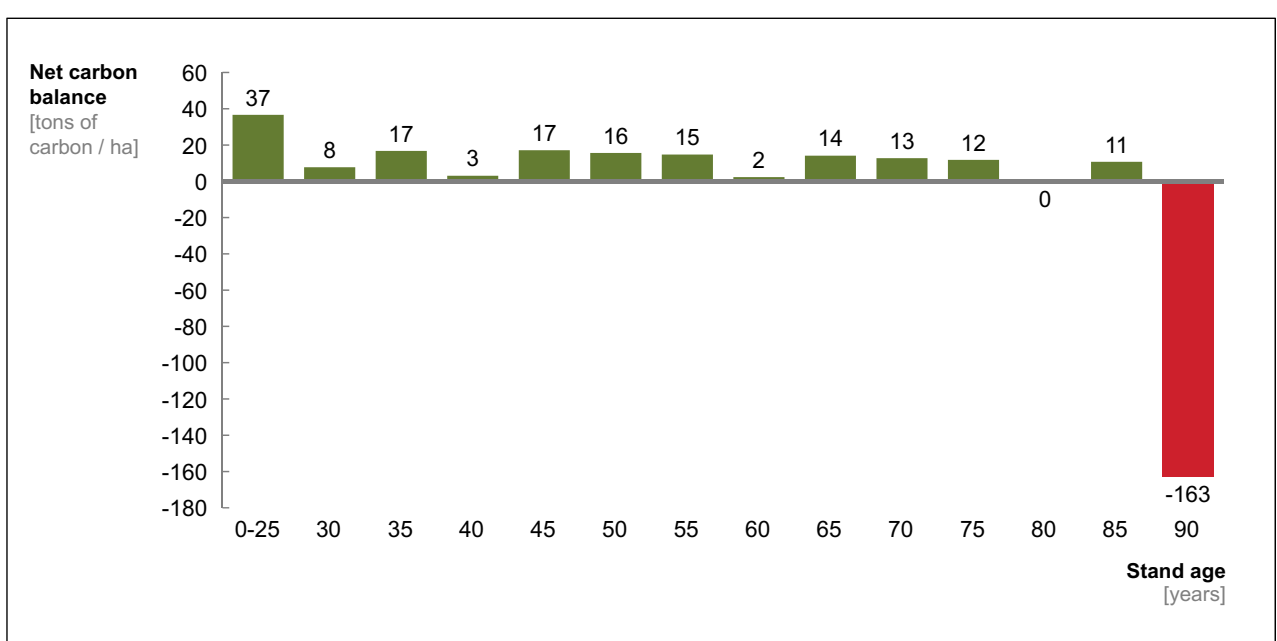

improved by early thinnings from above and with a low future crop tree number resulting in a low stocking density. The stand growth simulation of this research reaffirms this effect. The group selection system has the best, i.e., the lowest, h/DBH ratio of the average basal stand area tree at age 85 with 0.74 , followed by the thinning from above system with 0.80 , due to a higher future crop tree number and by the thinning from below system with 1.00 . Therefore, the trees in the thinning from below system are most unstable in case of a storm (cf. Section 3.1).

The CVaR, as well as the relative average loss, were also related to the standing stock of the stands. Higher standing stocks increase the risk of catastrophic losses, since there is a high amount of capital exposed. Amacher et al. (2010) report similar patterns studying the impacts of storm risk on harvesting patterns using the Faustmann framework. Albrecht et al. (2012) and also Pukkala et al. (2016) see a high standing stock as a factor that increases the collective stability. They acknowledge however that stock accumulations lead to potentially higher damages, especially when existing homogenous structures are disturbed by thinning activities.

It is worth noting that the storm model applied to our silvicultural scenarios is highly sensitive towards the vertical structure of the stands. Although we are not modeling a perfectly uneven-aged forest, we already could show that the increasing size diversity of the group selection system leads to an irregular vertical structure and a clustered stand decreases storm damage probability (cf. Fig. 6). Dobbertin (2002) and Pukkala et al. (2016) both confirm these effects in their research. Moreover, Hanewinkel et al. (2014) show that uneven-aged stands with a structure close to a J-shaped diameter-distribution are less prone to storm damage than even-aged stands. Norway spruce is still one of the most important tree species for southern Germany and is highly vulnerable to storms in this region (Hanewinkel et al. 2013). Thus, strategies to increase the stability of Norway spruce stands are needed. We highlight here that storm damage can also be mitigated through other management actions, such as promoting mixed forest stands with more stable trees. With a different tree species or even mixed species stands, we expect to generate less significant results regarding storm risk modeling. By shifting towards higher stability tree species, such as beech or oak (Quercus robur L.), the effect of storm damages is expected to be smaller, with albeit lower overall profitability (Dieter 2001). Finally, shifting from a single to a mixed species stand might be able to achieve both an increase in stand
Fig. 10 Net carbon balance of the thinning from above system throughout one rotation period in tons of carbon per hectare. Negative values show carbon release through timber harvesting

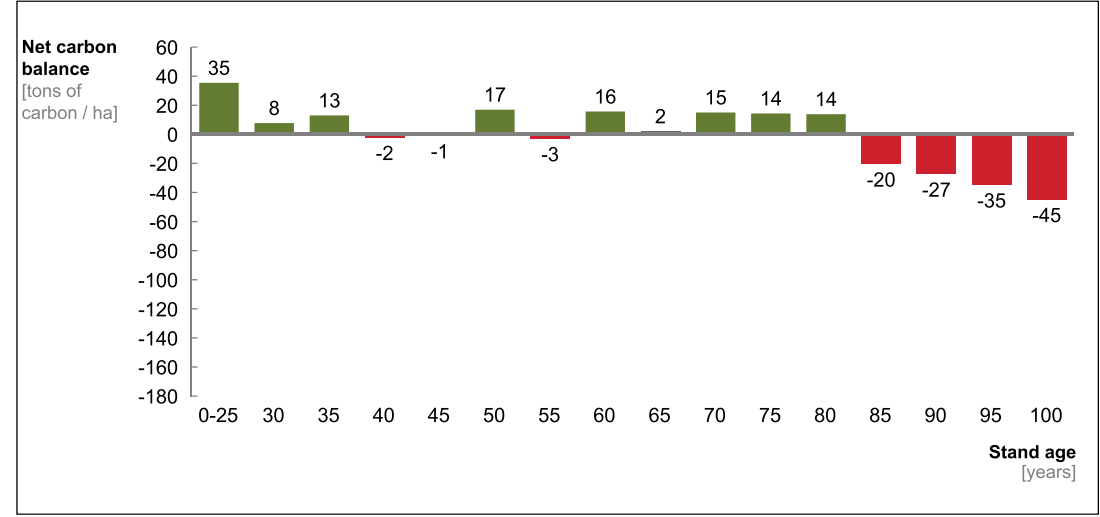




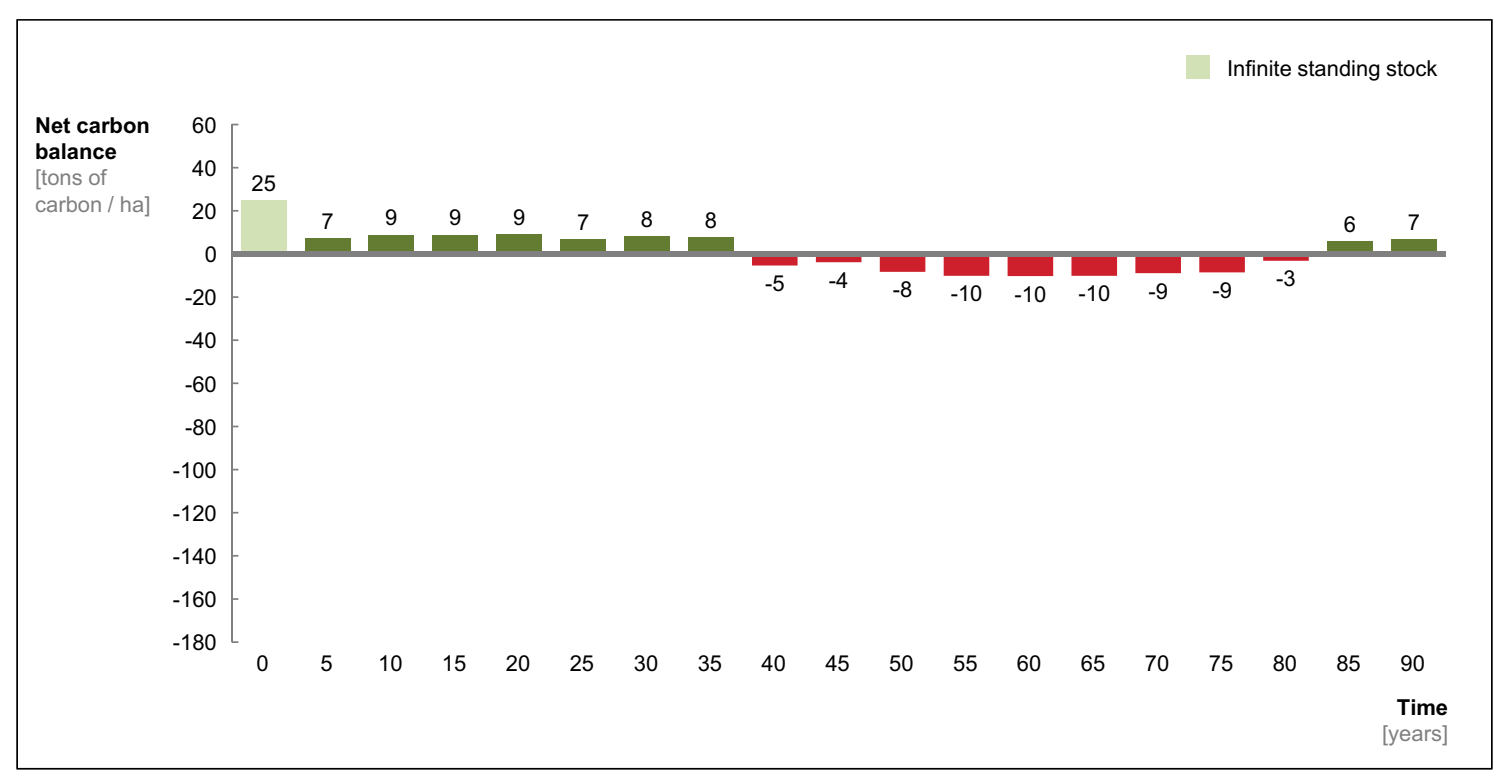

Fig. 11 Net carbon balance of the group selection system throughout one cutting cycle in tons of carbon per hectare. Negative values show carbon release through timber harvesting

stability and maintenance or even improvement of economic performance, depending on the site conditions (Griess and Knoke 2013). It would be worth further research to elaborate on both aspects discussed: an uneven-aged and a mixed species stand structure under the presence of storm risk from an economic perspective.

In addition, we would highlight that our damage model does not consider changes in the damage probability due to increased wind speed on stand edges after final harvestings (Jactel et al. 2009). The creation of edges due to, e.g., group cuttings may increase storm risk on stands. For example, Albrecht et al. (2012) modeled storm damage in Southwestern Germany using an extensive dataset and reported that after thinning, there is a limited period where the damage risk increases. We stress that for group selection, this effect is present at the stand scale, whereas for thinning from below and thinning from above, it occurs at landscape scale. Therefore, a further investigation of the impacts of these silvicultural systems at the landscape scale is warranted.

Table $5 \widehat{L E V}_{\text {carbon }}$ at the average carbon price level of 2009-2018

\begin{tabular}{lclc}
\hline & $\begin{array}{l}\text { Thinning from } \\
\text { below } \\
\text { [EUR (2016)] }\end{array}$ & $\begin{array}{l}\text { Thinning from } \\
\text { above } \\
\text { [EUR (2016)] }\end{array}$ & $\begin{array}{l}\text { Group } \\
\text { selection } \\
\text { [EUR (2016)] }\end{array}$ \\
\hline NPV rotation 1 & 1249 & 1044 & 1570 \\
NPV rotation 2 & 90 & 59 & 44 \\
NPV rotation 3 & 13 & 8 & 5 \\
NPV rotation 4 & 3 & 0 & 1 \\
$L E V_{\text {carbon, } 1 \%}$ & 1 & 2 & 1 \\
$\widehat{L E V}_{\text {carbon }}$ & 1356 & 1113 & 1621 \\
\hline
\end{tabular}

Finally, with respect to the quantitative measures introduced, we showed that the level of the absolute CVaR is also driven by the LEV without storm risk of the different silvicultural systems simulated. Therefore, the CVaR gives not only a sense about the stability of a stand but also its total economic performance under risk. Compared to that, the relative average loss from storm events is independent from the absolute LEV excluding storm risk. For the silvicultural systems defined in this paper, both measures indicate that the group selection system outperforms the thinning from below and thinning from above system in economic terms as well as regarding stand stability.

\subsection{Cost and price changes}

When looking at the sensitivity of the LEV towards the different cost and price levels observed throughout history, we see that the group selection system irrespective of its absolute LEV level shows the lowest sensitivity towards cost and price changes throughout history, whereas the thinning from below system shows the highest sensitivity, with the lowest signalto-noise ratio. We can conclude that the following characteristics of the simulated group selection system decrease sensitivity towards cost and price changes:

- High harvest efficiency, driven by a high volume per tree ratio. The labor costs increase in such a system, but so does the harvesting efficiency and the latter outweighs the labor cost effect.

- Focus on the production of valuable assortments (e.g., crop tree orientation). Silvicultural systems targeting the production of valuable trees maintains the economic 
performance of a forest stand, since the timber market thus far in history always values quality and dimension with higher timber prices, compared to mass assortments.

- Reduction in forest investments and enhancement of the use of natural regeneration. Labor cost changes for planting are directly affecting the LEV without discounting effects and therefore can seriously endanger the economic performance of a forest stand right at the beginning of the rotation period.

Finally, we point out in this paper that the general economic performance of different silvicultural systems not taking storm risk into account was intentionally not discussed in detail. The economic performance excluding storm risk of silvicultural systems is driven by a diverse set of factors, ranging from tree species composition, via site quality, to rotation period and level of industrialization (Knoke 2012; Pukkala et al. 2012). Therefore, it would be inappropriate to generalize that CCF systems, such as the group selection system, always outperform rotation forest systems such as the thinning from below and the thinning from above system. As the purpose of this paper is not to compare the performance of the best possible rotation forest management approach with the best possible CCF approach of the present, we will not further discuss this topic here and refer to the ongoing scientific discussion about this issue (Knoke 2012). The systems defined in this paper, however, can be seen as valid and representative for the historical development of silvicultural systems in Central Europe. For the group selection system, we are aware that a forest stand treated in the form of a group selection might not represent a perfectly uneven-aged forest but rather a designed continuous cover forest. Depending on the definition of uneven-aged forestry, the group selection system might be seen more as a clustered form of an even-aged forest on stand level (Kuuluvainen et al. 2012). However, as we limit our analyses on Norway spruce stands (cf. Section 2.2), we chose to simulate a group selection system as a typical system for this species, whereas uneven-aged Norway spruce stands are an exception and normally a rather small portion in a mixed forest stand of, e.g., silver fir (Abies alba Mill.) and European beech (Fagus sylvatica L.) (ForstBW 2014).

\subsection{Carbon sequestration}

As outlined in Section 3.3, revenues from carbon sequestration can be an important part of the revenues generated by a forest stand. The $L E V_{\text {carbon }}$ is similar for the different systems (cf. Table 5). Due to the positive effect of the standing stock accounted for in the first rotation, the group selection system outperforms the thinning from below and thinning from above systems, although its total carbon uptake is the lowest (cf. Müller et al. (2019), R2, Fig. PR6). When only looking at the periodical physical carbon uptake per rotation, the biomass accumulation strategy in the thinning from below system is performing best in an environment without storm risk.

Although storms may have a significant effect on the physical carbon balance of forests (Lindroth et al. 2009; Thürig et al. 2005), we assume that carbon release from storms is not accounted in the LEV as negative cash flow. Furthermore, as we assumed that damaged stand areas are immediately replaced, losses in carbon sequestration performance are also minor. Finally, the given carbon price is leading to comparably minor cash flows compared to timber harvesting-induced cash flows. Therefore, the overall effect of carbon sequestration on the $L E V_{\text {total }}$ under storm risk is minor (cf. Section 3.3). However, under the assumption that a landowner must pay for carbon emission emitted due to natural hazards, this effect would significantly increase with direct consequences on forest management decisions (Stainback and Alavalapati 2002).

It can be concluded that silvicultural systems, which only aim at in situ physical carbon sequestration, should focus on total volume growth and minor thinning activities, more than on future crop trees and generating optimal products for timber industries. However, when including storm risk, losses in physical carbon may counteract the positive effect of carbon accumulation systems (Lindroth et al. 2009; Thürig et al. 2005). As we focused our analysis on the economic performance, meaning the $L E V_{\text {carbon }}$, we are not able to draw a conclusion about the extent of this effect. Furthermore, as we did not consider the technosphere, meaning the carbon sequestration effect of harvested timber products, we cannot analyze the positive effect of silvicultural systems focusing on producing long-term sequestering timber products (Sedjo and Sohngen 2012; Skog 2008). Moreover, when considering the impact of clearcuts on the soil carbon stock, which was also not included in this research, classical rotation forest management systems might lag behind a CCF approach (Jandl et al. 2007).

\section{Conclusion}

In this article, we showed that the adaptation of the silvicultural systems throughout history has led to an increase of their mitigation efficiency towards storm risk. The lowest relative average loss and highest $\mathrm{CVaR}$ are achieved within the group selection system, followed by conservative thinning from above and thinning from below systems. We could also point out that the effect of storm risk on the economic profits generated from carbon sequestration is minor, mainly driven by the fact that carbon release from natural hazards is not leading to negative cash flows in the $L E V_{\text {carbon }}$.

Furthermore, we demonstrated that cost and price changes are significantly affecting the economic performance of a forest stand with varying effects on different silvicultural systems. The thinning from below system turns out to be highly 
sensitive towards cost and price changes, whereas the group selection system displays the lowest sensitivity. Although the model and scenarios defined in this paper are restricted and can be further extended as discussed, we could identify important characteristics of silvicultural systems that contribute to decreasing the sensitivity to cost and price changes of a forest stand, such as crop tree orientation and natural regeneration.

We can conclude that silvicultural systems can contribute to increasing storm risk mitigation efficiency and also contribute to decreasing sensitivity towards cost and price changes. However, even if there is willingness for silvicultural adaptation, achieving measurable effects in the forest needs decades. As the huge storm damage of 1990 and 2000 in Germany showed, silvicultural adaptation, beginning already in the middle of the twentieth century, was not enough to mitigate storm damages noticeably. In the context of the prevalent uncertainties from climate change and its multiple effects on the biosphere, silvicultural management must adapt even faster. Therefore, forest research is asked to develop forest management strategies which accelerate silvicultural adaptation and facilitate this process of adaptation with appropriate organizational processes and structures to manage disruptions from natural hazards efficiently.

\section{Public repository}

This article is accompanied with a public repository (Müller et al. 2019) which can be accessed online, containing dataset and analyses this article is based on, as well as additional data figures and deep dives on the methodological background this paper has built on.

Acknowledgments Special thanks to the Forestry Research Institute (FVA) of Baden-Württemberg for providing valuable historical data about silviculture and forest operations in Germany.

Funding information This research did not receive any specific grant from funding agencies in the public, commercial, or non-profit sectors.

\section{Compliance with ethical standards}

Conflict of interest The authors declare that they have no conflict of interest.

Data deposition information includes a weblink: https://zenodo.org/ $\operatorname{record} / 2636500$

\section{References}

Abetz P (1975) Entscheidungshilfen für die Durchforstung von Fichtenbeständen: Durchforstungshilfe Fi 1975. Merkblätter der forstlichen Versuchs- und Forschungsanstalt Baden-Württemberg, Freiburg
Albrecht A (2009) Sturmschadensanalysen langfristiger waldwachstumskundlicher Versuchsflächendaten in BadenWürttemberg. Doctoral thesis, Albert-Ludwigs-University

Albrecht A, Hanewinkel M, Bauhus J, Kohnle U (2012) How does silviculture affect storm damage in forests of south-western Germany? results from empirical modeling based on long-term observations. Eur J For Res 131:229-247. https://doi.org/10.1007/s10342-0100432-x

Albrecht A, Fortin M, Kohnle U, Ningre F (2015) Coupling a tree growth model with storm damage modeling - conceptual approach and results of scenario simulations. Environ Model Softw 69:63-76. https://doi.org/10.1016/j.envsoft.2015.03.004

Albrecht AT, Jung C, Schindler D (2019) Improving empirical storm damage models by coupling with high-resolution gust speed data. Agr Forest Meteorol 268:23-31

Amacher GS, Koskela E, Ollikainen M (2010) Economics of forest resources. MIT Press, Cambridge

Brazee RJ (2018) Impacts of declining discount rates on optimal harvest age and land expectation values. J For Econ 31:27-38. https://doi. org/10.1016/j.jfe.2017.06.002

Carbon Pulse (2018) EU ETS: news and intelligence on carbon markets, greenhouse gas pricing and climate policy. https://carbon-pulse. com/52835/

Chang SJ (1998) A generalized Faustmann model for the determination of optimal harvest age. Can J For Res 28:652-659

Creedy J, Wurzbacher AD (2001) The economic value of a forested catchment with timber, water and carbon sequestration benefits. Ecol Econ 38:71-83. https://doi.org/10.1016/S0921-8009(01) 00148-3

Davies O, Kerr G (2015) Comparing the costs and revenues of transformation to continuous cover forestry for sitka spruce in Great Britain. Forests 6:2424-2449. https://doi.org/10.3390/f6072424

Dieter M (2001) Land expectation values for spruce and beech calculated with Monte Carlo modelling techniques. Forest Policy Econ 2:157166. https://doi.org/10.1016/S1389-9341(01)00045-4

Dieter M, Elsasser P (2002) Carbon stocks and carbon stock changes in the tree biomass of Germany's forests. Forstwissenschaftliches Centralblatt 121:195-210. https://doi.org/10.1046/j.1439-0337. 2002.02030.x

Dobbertin M (2002) Influence of stand structure and site factors on wind damage comparing the storms Vivian and Lothar. For Snow Landsc Res 77:187-205

Duncker PS, Raulund-Rasmussen K, Gundersen P, Katzensteiner K, de Jong J, Ravn HP, Smith M, Eckmüllner O, Spiecker H (2012) How forest management affects ecosystem services, including timber production and economic return: synergies and trade-offs. Ecol Soc 17

Endres M (1895) Lehrbuch der Waldwertrechnung und Forststatistik. Springer, Berlin Heidelberg

Faustmann M (1849) Berechnung des Wertes welchen Walboden sowie noch nicht haubare Holzbestande fur die Waldwirtschaft besitzen. Algemeine Forst-and Jagd-Zeitung 15

ForstBW (2014) Richtlinie landesweiter Waldentwicklungstypen. Landesbetrieb Forst Baden-Württemberg, Ministerium für Ländlichen Raum und Verbraucherschutz. http://www.forstbw.de/ fileadmin/forstbw_infothek/forstbw_praxis/wet/ForstBW Waldentwicklung_web.pdf. Accessed 22 Sept 2018

German Central Bank (2017) Kaufkraftvergleiche historischer Geldbeträge. https://www.bundesbank.de/Redaktion/DE/ Standardartikel/Statistiken/kaufkraftvergleiche_historischer geldbetraege.html. Accessed 12 Nov 2017

Griess VC, Knoke T (2013) Bioeconomic modeling of mixed Norway spruce - European beech stands: economic consequences of considering ecological effects. Eur J Forest Res 132:511-522. https://doi. org/10.1007/s10342-013-0692-3 
Gutrich J, Howarth RB (2007) Carbon sequestration and the optimal management of New Hampshire timber stands. Ecol Econ 62:441450. https://doi.org/10.1016/j.ecolecon.2006.07.005

Haight R, Smith DW, Straka JT (1995) Hurricanes and the economics of loblolly pine plantations. For Sci 41:675-688

Hanewinkel M, Cullmann DA, Schelhaas M-J, Nabuurs G-J, Zimmermann NE (2013) Climate change may cause severe loss in the economic value of European forest land. Nat Clim Chang 3:203207. https://doi.org/10.1038/nclimate1687

Hanewinkel M, Kuhn T, Bugmann H, Lanz A, Brang P (2014) Vulnerability of uneven-aged forests to storm damage. Forestry 87:525-534. https://doi.org/10.1093/forestry/cpu008

Hartig GL (1791) Anweisung zur Holzzucht für Förster. Neue akademische Buchhandlung, Marburg

Hein S, Herbstritt S, Kohnle U (2007) Auswirkung der Z-BaumAuslesedurchforstung auf Wachstum, Sortenertrag und Wertleistung im europäischen Fichten-Stammzahlversuch (Picea abies [L.] Karst.) in Südwestdeutschland. Allgemeine Forst und Jagdzeitung 179:192-201

Jactel H, Nicoll BC, Branco M, Gonzalez-Olabarria JR, Grodzki W, Långström B, Moreira F, Netherer S, Orazio C, Piou D, Santos H, Schelhaas MJ, Tojic K, Vodde F (2009) The influences of forest stand management on biotic and abiotic risks of damage. Ann For Sci 66:701. https://doi.org/10.1051/forest/2009054

Jandl R, Lindner M, Vesterdal L, Bauwens B, Baritz R, Hagedorn F, Johnson DW, Minkkinen K, Byrne KA (2007) How strongly can forest management influence soil carbon sequestration? Geoderma 137:253-268. https://doi.org/10.1016/j.geoderma.2006.09.003

Knoke T (2012) The economics of continuous cover forestry. In: Pukkala T, Gadow K (eds) Continuous cover forestry. Springer Netherlands, Dordrecht, pp 167-194

Kublin E, Bösch B (2007) BDAT-das Sorten-und Volumenprogramm. Forestry Research Institute (FVA) of Baden-Württemberg. http:// www.fva-bw.de/indexjs.html?, http://www.fva-bw.de/forschung/ bui/bdat.html. Accessed 16 Nov 2017

Kuuluvainen T, Tahvonen O, Aakala T (2012) Even-aged and unevenaged forest management in boreal Fennoscandia: a review. Ambio 41:720-737. https://doi.org/10.1007/s13280-012-0289-y

Lindner M, Maroschek M, Netherer S, Kremer A, Barbati A, GarciaGonzalo J, Seidl R, Delzon S, Corona P, Kolström M, Lexer MJ, Marchetti M (2010) Climate change impacts, adaptive capacity, and vulnerability of European forest ecosystems. For Ecol Manag 259: 698-709. https://doi.org/10.1016/j.foreco.2009.09.023

Lindroth A, Lagergen F, Grelle A, Klemedtsson L, Langvall O, Weslien P, Tuulik J (2009) Storms can cause Europe-wide reduction in forest carbon sink. Glob Chang Biol 15:346-355. https://doi.org/10.1111/ j.1365-2486.2008.01719.x

Loisel P (2011) Faustmann rotation and population dynamics in the presence of a risk of destructive events. J For Econ 17:235-247. https:// doi.org/10.1016/j.jfe.2011.02.001

Loisel P (2014) Impact of storm risk on Faustmann rotation. Forest Policy Econ 38:191-198. https://doi.org/10.1016/j.forpol.2013.08.002

Lundmark T, Bergh J, Nordin A, Fahlvik N, Poudel BC (2016) Comparison of carbon balances between continuous-cover and clear-cut forestry in Sweden. Ambio 45(Suppl 2):203-213. https:// doi.org/10.1007/s13280-015-0756-3

Müller F, Hanewinkel M (2018) Challenging the assumptions of a standard model: how historical triggers in terms of technical innovations, labor costs and timber price change the land expectation value. Forest Policy Econ 95:46-56. https://doi.org/10.1016/j.forpol.2018. 07.009

Müller F, Lessa Derci Augustynczik A, Hanewinkel M (2019) Supplementary material for research article "Quantifying the risk mitigation efficiency of changing silvicultural systems under storm risk throughout history". V2. Zenodo. [Dataset]. https://doi.org/10. 5281/zenodo. 2636500
Nagel J, Duda H, Hansen J (2017) Forest simulator BWINPro 7. https:// www.nw-fva.de/?id=194. Accessed 4 Oct 2017

Newell RG, Pizer WA (2003) Discounting the distant future: how much do uncertain rates increase valuations? J Environ Econ Manag 46: 52-71. https://doi.org/10.1016/S0095-0696(02)00031-1

Newman DH (2002) Forestry's golden rule and the development of the optimal forest rotation literature. J For Econ 8:5-27. https://doi.org/ 10.1078/1104-6899-00002

Oxera Consulting LLP (2002) Social time preference rate for use in longterm discounting, London. https://www.oxera.com/publications/asocial-time-preference-for-use-in-long-term-discounting/. Accessed 24 Aug 2018

Pukkala T, Lahde E, Laiho O (2012) Continuous cover forestry in Finland - recent research results. In: Pukkala T, Gadow K (eds) Continuous cover forestry. Springer Netherlands, Dordrecht

Pukkala T, Laiho O, Lähde E (2016) Continuous cover management reduces wind damage. For Ecol Manag 372:120-127. https://doi. org/10.1016/j.foreco.2016.04.014

Rakotoarison H, Loisel P (2017) The Faustmann model under storm risk and price uncertainty: a case study of European beech in northwestern France. Forest Policy Econ 81:30-37. https://doi.org/10.1016/j. forpol.2017.04.012

Reed WJ (1984) The effects of the risk of fire on the optimal rotation of a forest. J Environ Econ Manag 11:180-190. https://doi.org/10.1016/ 0095-0696(84)90016-0

Schelhaas M-J, Nabuurs G-J, Schuck A (2003) Natural disturbances in the European forests in the $19^{\text {th }}$ and $20^{\text {th }}$ centuries. Glob Chang Biol 9:1620-1633. https://doi.org/10.1046/j.1365-2486.2003.00684.x

Schmidt M, Hanewinkel M, Kändler G, Kublin E, Kohnle U (2010) An inventory-based approach for modeling single-tree storm damageexperiences with the winter storm of 1999 in southwestern Germany. Can J For Res 40:1636-1652. https://doi.org/10.1139/ X10-099

Sedjo R, Sohngen B (2012) Carbon sequestration in forests and soils. Ann Rev Resour Econ 4:127-144. https://doi.org/10.1146/ annurev-resource-083110-115941

Skog KE (2008) Sequestration of carbon in harvested wood products for the United States. For Prod J 58(6):56-72

Stainback GA, Alavalapati JR (2002) Economic analysis of slash pine forest carbon sequestration in the southern US. J For Econ 8:105117. https://doi.org/10.1078/1104-6899-00006

Thürig E, Palosuo T, Bucher J, Kaufmann E (2005) The impact of windthrow on carbon sequestration in Switzerland: a model-based assessment. For Ecol Manag 210:337-350. https://doi.org/10.1016/j. foreco.2005.02.030

Tonosaki M (2009) Harvested wood products accounting in the post Kyoto commitment period. J Wood Sci 55:390-394. https://doi. org/10.1007/s10086-009-1052-2

Treasury HM (2003) The green book: appraisal and evaluation in central government. The Stationery Office, London

Wäldchen J, Schulze E-D, Schöning I, Schrumpf M, Sierra C (2013) The influence of changes in forest management over the past 200years on present soil organic carbon stocks. For Ecol Manag 289:243254. https://doi.org/10.1016/j.foreco.2012.10.014

Weitzman ML (2001) Gamma discounting. Am Econ Rev 91:260-271

Yousefpour R, Hanewinkel M (2009) Modelling of forest conversion planning with an adaptive simulation-optimization approach and simultaneous consideration of the values of timber, carbon and biodiversity. Ecol Econ 68:1711-1722. https://doi.org/10.1016/j. ecolecon.2008.12.009

Publisher's note Springer Nature remains neutral with regard to jurisdictional claims in published maps and institutional affiliations. 